\title{
The Functions of the International Law Commission: Identifying Existing Law or Proposing New Law?
}

\author{
Ineta Ziemele
}

I Introduction*

The question in the title of this article was suggested by the organizers of the International Law Commission's seventieth anniversary seminar. Before addressing the question, that is looking at the codification and development of international law, it is necessary to reflect on a broader issue relating to the functions of the Commission at a time marked by the plurality of actors on the international stage, their growing interdependence and the fact that these processes called globalization "seem to be beyond the control of even the most economically and militarily powerful States". ${ }^{1}$ International law-making is clearly no longer the exclusive competence of States, ${ }^{2}$ but the Commission continues to emphasize the primary role of States. Furthermore, it must be recognized that State consent is not a single given act; it is part of a complex process of interactions. Placed within the new context of law-making, this view of State consent as a process accepts in some manner the plurality of actors and their influence on States.

The question of the content and purpose of the International Law Commission's functions, i.e., of the role of the Commission today, has to be reviewed within this new context of international law-making and the results of this review should consistently be taken into account.

* The author is grateful to Kristaps Tamužs and Gatis Bārdin̄š of the Constitutional Court of Latvia for their research assistance in the preparation of this text.

1 James Crawford, 'Chance, Order, Change: The Course of International Law' (2013) 365 RdC 9, 109 .

2 Conclusion 4. [..] 3. Conduct of other actors is not practice that contributes to the formation, or expression, of rules of customary international law, but may be relevant when assessing the practice referred to in paragraphs 1 and 2. Conclusion 5. [..] 2. Other conduct, including by non-State actors, does not constitute subsequent practice under articles 31 and 32 . Such conduct may, however, be relevant when assessing the subsequent practice of parties to a treaty; see ILC, 'Draft conclusions on identification of customary international law' (2018) $\mathrm{UN} \operatorname{Doc} \mathrm{A} / 73 / 10,122$. 
Among the relevant concepts that capture the changing nature of the international law landscape are accountability, democracy, civil society, transparency, the international rule of law and constitutionalization. There is by now a considerable amount of scholarship posing questions about the new or changing nature of the international legal system. Certainly, the density of this scholarship and the examples of international normative practices that feed into this debate have grown over the last decades. A fair characterization as to where we are today has been provided by James Crawford in his Hague Academy lectures:

There are certainly subfields of international law that can be described more or less accurately as having been legalized by means of multilateral framework treaties [...]. The existence of these potentially constitutionalized sectoral regimes and the fact that there is no hierarchy that can determine the outcome of conflicts between them might suggest that the international system is characterized not by a single constitution for an international society, but by many - and therefore by none. ${ }^{3}$

Despite this negative conclusion, Crawford returns to this point later in acknowledging that the "notion of a constitutional order in which domestic, regional and sectoral orders coexist and complement each other is somewhat more plausible than the idea of a single instrument".

There are indeed by now several treaty regimes that have entered a constitutionalization stage. They co-exist in a decentralized and horizontal relationship which is constantly evolving because international law remains a process of claim and counterclaim, assertion and reaction by the plurality of subjects and actors. ${ }^{5}$ One can add that domestic constitutional orders have come to have an increasing role in this process through the direct application and interpretation of international rules by domestic courts and their use by the political branches of power. We are increasingly seeing that international law-making processes and domestic legal systems are parts of

3 James Crawford (n 1$) 463$.

4 Ibid 465-466.

5 Ibid 2o. See also Jan Klabbers, 'Setting the Scene' in Jan Klabbers, Anne Peters, and Geir Ulfstein (eds), The Constitutionalization of International Law (oup 2009) 1. 
a single universal legal process, if not a system, even if at a rather rudimentary level.

The International Law Commission has also come to recognize this development. In the conclusions on subsequent agreements and subsequent practice in relation to interpretation of treaties under articles 31 and 32 of the Vienna Convention on the Law of Treaties, ${ }^{6}$ "subsequent practice" refers to "any conduct of a party in the application of a treaty, whether in the exercise of its executive, legislative, judicial or other function". ${ }^{7}$ Conclusion 6 describes the forms of State practice which "include, but are not limited to: diplomatic acts and correspondence; conduct in connection with resolutions adopted by an international organization or at an intergovernmental conference; conduct in connection with treaties; executive conduct, including operational conduct 'on the ground'; legislative and administrative acts; and decisions of national courts".8

These developments are further reflected in the debate on the sources of international law. Does the current list of sources of international law and Article 38 of the Statute of the International Court of Justice form the backbone of the international legal system when new sources have emerged which are not listed in Article 38 ? I believe that the debate on whether Article 38 is a kind of rule of recognition in international law, or whether the emergence of new sources of law challenges that view, is in fact a debate on whether the glass is half-full or half-empty. ${ }^{9}$ There is no question that the primary sources of international law have been identified and are there to stay, but similar to the processes in democratic legal systems additional sources emerge over periods of time. I shall give an example.

In some domestic legal systems, it has become very clear that the caselaw of domestic courts and judge-made law constitute a source of law. ${ }^{10}$ The debate on the legal nature of the caselaw of international courts has also been evolving. I have argued elsewhere that, for example, the caselaw of the European

6 Adopted 23 May 1969, entered into force 27 January 1980, 1155 UNTS 331.

7 See ILC, 'Draft conclusions on subsequent agreements and subsequent practice in relation to the interpretation of treaties' (2018) UN Doc A/73/10, conclusion 5 .

8 See ILC, 'Draft conclusions on subsequent agreements and subsequent practice in relation to the interpretation of treaties' (2018) UN Doc A/73/10, conclusion 5 .

9 Jan Klabbers, 'Law-making and Constitutionalism' in Jan Klabbers, Anne Peters, and Geir Ulfstein (eds), The Constitutionalization of International Law (oup 20o9) 87; Samantha Besson, 'Theorizing the Sources of International Law' in Samantha Besson and John Tasioulas (eds) The Philosophy of International Law (Oup 2010) 181-182.

10 Daiga Rezevska, 'Judikatūra kā tiesību avots: izpratne un pielietošana' (2010) 1 Latvijas Republikas Augstākās tiesas Biletens 31. 
Court of Human Rights has become more then lex interpretata - it is a source of European human rights law.11

To sum up, the international legal system is composed of a plurality of actors and sources of law and has multiple, sometimes competing, potentially constitutional regimes. If we agree that these are the features of the international law landscape today, then the functions of the International Law Commission, and, in particular, its methods of work, should be revised accordingly. I would argue that even after such a revision, taking into account the current features of the international legal landscape, there remains a choice to be made with regard to the kind of role the International Law Commission ought to play in this context. It is always possible to take either a broader or a narrower view on its role.

\section{Proposition for a Broader View on the International Law Commission's Functions}

The International Law Commission continues to be an independent expert body which responds to the requests of the Sixth Committee of the General Assembly. It has been pointed out that these characteristics of the International Law Commission are a source of both its strength and its weakness. They have enabled it to provide a deliberative and often authoritative process for the codification and, to a modest degree, the progressive development of general international law. ${ }^{12}$ On the fiftieth anniversary of the International Law Commission, the Study Group within the auspices of the British Institute of International and Comparative Law reviewed the work and the methods of the Commission. It is interesting to note that already then, the Study Group pointed to the changing landscape of international law. It came to the conclusion that the Commission should have a broader law-making role which would require a number of adjustments. ${ }^{13}$ The Commission "could assume a more progressive role in a number of areas and that a re-conceived, more innovative Commission which co-operated more closely with other bodies while maintaining its unique strength of drawing on knowledge of the

11 Ineta Ziemele, 'Case Law of the European Court of Human Rights as s Source of Human Rights' (2020) 17 BaltYIL Online 143 (forthcoming).

12 Michael Anderson, Alan Boyle, Vaughan Lowe and Chanaka Wickremasinghe (eds), The International Law Commission and the Future of International Law (BIICL 1998) 22.

13 Ibid 49 . 
international legal system as a whole, has much to offer". ${ }^{14}$ I share the conclusions of the Study Group and submit that the Commission should further build on them.

The new features of the international legal landscape have also given rise to such new debates as fragmentation, conflicts of rules and regimes. These debates are a reflection on the perceived weakness of the international legal system when confronted with a growing plurality of actors and density of legal regimes while maintaining a system of horizontal sources of law with a very limited hierarchy. Also, what could be called the downside of the changing nature of the international legal landscape, requires the continued evolution of the role of the International Law Commission. The new role of the Commission needs to be articulated conceptually and not only at the level of working methods and the types of output, which the Commission has already diversified to some extent.

I would thus like to situate the role of the International Law Commission within a pluralist vision of the world and the international normative process therein. Let me recall the constitutional pluralist discourse as regards the plurality of constitutional sites and the way to address it, i.e., "what is required in acknowledging and handling competing claims to authority coming from national and supranational constitutional sites is an ethic of political responsibility premised on mutual recognition and respect". ${ }^{15}$ Competing claims to authority typically are channeled through the development of legal norms either within international, regional or domestic legal orders. One can mention a strong example of such a claim to authority which unless further explained may lead to the isolation of a particular legal regime. For example, the Court of Justice of the European Union, in deciding on measures to counter terrorism in the Kadi case, insisted that the European Community had high fair trial standards when compared to those used by the United Nations Security Council. The Court of Justice recalled that:

In this connection it is to be borne in mind that the Community is based on the rule of law, inasmuch as neither its Member States nor its institutions can avoid review of the conformity of their acts with the basic constitutional charter, the EC Treaty, which established a complete system of

14 Ibid.

15 Jean L Cohen, 'Sovereignty in the Context of Globalization: A Constitutional Pluralist Perspective' in Samantha Besson and John Tasioulas (eds) The Philosophy of International Law (OUP 2010) 275; Klabbers (n 10) 29-30. 
legal remedies and procedures designed to enable the Court of Justice to review the legality of acts of the institutions. ${ }^{16}$

In view of the plurality of such legal orders and their oftentimes competing claims to authority, the key to harmonious development of a more universal legal order lies in mutual recognition and respect.

It is therefore clear that today the International Law Commission ought to have the capacity to survey the normative claims across the plurality of actors such as states, international and regional organizations, international and regional courts, supranational and national constitutional orders, and to have the methodology that can distinguish normative claims from other types of practice. The role of the Commission in fulfilling its functions of codification and development of law is to reach out to those actors whose actions may decisively impact the formation and application of legal rules at an international level. Pluralism works towards a certain democratic nature of the international normative landscape. Since the establishment of the United Nations an understanding emerged that for its decisions to have a "compliance pull", ${ }^{17}$ the process of their adoption should take into account the views of as many States as possible around the world. Certainly, the composition of the International Law Commission tends to reflect all the major legal systems and cultures. Where one is able to capture the modern phenomenon of a growing plurality of actors, it contributes to the overall legitimacy of the exercise of power at an international level. There is no doubt that also the International Law Commission, in carrying out its functions of codification or development of international law, exercises power. It is therefore suggested that the Commission should reflect on the various aspects of legitimacy of its work, including input legitimacy and not only output legitimacy. ${ }^{18}$

The Study Group of the British Institute of International and Comparative Law had already proposed that the Commission should actively engage the co-operation of other inter-governmental actors and also the legal profession. It can only be reiterated that openness and accessibility of the Commission's working processes should be encouraged. ${ }^{19}$

A further democratization of the working methods of the Commission is necessary if it is to strengthen its legitimacy and maintain its role as the

16 C-402/05 P Kadi [2008] ECR I-06351, para 281; see also C-294/83 Les Verts v Parliament [1986] ECR o1339, para 23.

17 Thomas M Franck, The Power of Legitimacy among Nations (OUP 1990), 234.

18 For more on legitimacy, see Klabbers (n 9) 37-43.

19 Anderson, Boyle, Lowe and Wickremasinghe (n 12) 51. 
principal body of legal expertise on general international law. States ought not to be the sole dialogue partners either through the Sixth Committee or other inter-governmental entities. A more organized and transparent network of non-State actors and scholars with interest and expertise in the work of the International Law Commission needs to be put in place. Some thought should go into democratizing the ways of receiving input for the work programme of the Commission. In this regard, regular meetings could be held with regional courts and ad hoc tribunals.

Given that constitutional courts have also formed joint forums of discussion, such platforms as the World Congress of Constitutional Courts as well as the European Conference of Constitutional Courts could be useful interlocutors. There are several reasons why the International Law Commission should not only follow the jurisprudence of the international and highest national courts but should also develop a dialogue with those courts for the purposes of its broader role in carrying out the functions of codifying and developing international law. These courts apply international law, follow the work of the International Law Commission and by now certainly engage in some law-making. Let me use the example of the European Court of Human Rights.

\section{Engagement of the European Court of Human Rights with the Work of the International Law Commission}

It is generally known that the European Court of Human Rights has consistently declared that it interprets the European Convention on Human Rights in accordance with the rules of interpretation of treaties as enshrined in the Vienna Convention on the Law of Treaties. In order to determine the meaning of the terms and phrases used in the European Convention on Human Rights, the Court is guided mainly by articles 31 to 33 of the Vienna Convention on the Law of Treaties. ${ }^{20}$ However, the Court does not take a dogmatic approach to the wording of article 31 nor to the sequence in which this article lists the methods of interpretation. As evidenced by the language of Demir and Baykarav Turkey, the Court may not be too concerned as to whether the State has ratified the treaty or whether the common domestic practices emerge specifically in the application of the European Convention, as the wording of article

20 Adopted 23 May 1969, entered into force 27 January 1980, 1155 UNTS 331. See, for instance, Golder v United Kingdom (1975) Series A no 18, para 29; Johnston and Others v Ireland (1986) Series A no 112, para 51; Witold Litwa v Poland ECHR 2000-III 289, paras 57-59. 
31, paragraph 3, would indicate. ${ }^{21}$ The Court is interested in seeing the common developments and trends relevant to the scope of the European Convention without necessarily identifying the binding character of those developments and practices. In other words, while article 31 of the Vienna Convention on the Law of Treaties offers a frame of reference for the Court as such, the Court has followed the methods of interpretation with a certain flexibility. ${ }^{22}$

In view of the pending work of the International Law Commission with regard to the "Immunity of State officials from foreign criminal jurisdiction", I will refer to two cases of the European Court on Human Rights. In Al-Adsani and Jones, which concerned the jurisdictional immunity of states or state officials from civil claims concerning torture, the European Court of Human Rights was required to ascertain the contents of international law rules in this area and their interplay with the right to a fair trial provided for in article 6 of the European Convention, that is whether the relevant domestic courts, when restricting the applicants' right of access to a court, had pursued a legitimate aim which was "complying with international law to promote comity and good relations between States through the respect of another State's sovereignty". ${ }^{3}$ In other words, the Court had to establish whether the domestic courts had correctly applied the rules of international law that existed at the time when they examined the case. If that was the case, then the "measures taken by a High Contracting Party which reflect generally recognised rules of public international law on State immunity cannot in principle be regarded as imposing a disproportionate restriction on the right of access to a court as embodied in Article 6 § 1..24

The obligation incumbent upon domestic courts in this regard can be said to be both procedural and substantive. The procedural obligation is to "fully engag $[\mathrm{e}]$ with all of the relevant arguments" concerning the state of international law at the relevant time. ${ }^{25}$ The substantive obligation is to reach conclusions that are not "manifestly erroneous nor arbitrary, but [are] based on extensive references to international-law materials and consideration of the applicants' legal arguments". 26

\footnotetext{
21 Demir and Baykara $v$ Turkey App no 34503/97 (ECtHR, 12 November 2008).

22 See further, Ineta Ziemele 'European consensus and international law' in Anne van Aaken and Iulia Motoc (eds), The European Convention on Human Rights and General International Law (OUP 2018).

23 Jones and others $v$ United Kingdom App nos 34356/06 and 40528/o6 (ECtHR, 14 January 2014), para 188.

24 Al-Adsaniv United Kingdom App no 35763/97 (ECtHR, 21 November 2001) para 56.

25 Jones (n 23) para 214.

26 Ibid.
} 
The European Court of Human Rights is charged with the task of verifying whether domestic courts have complied with these obligations. In order to do so, the Court has to embark upon independent research to reach its own conclusions about what international law provides. This is because the Court does not apply the European Convention in a vacuum. However, the Court only has a mandate to interpret and apply the European Convention. So it has to rely on the interpretation of other relevant rules of international law provided for by those with the relevant competence. Clearly, one of the most important sources of information that enables the European Court of Human Rights to form its own opinion on what international law requires is the work of the International Law Commission. For the specific function of any court, it is important to clearly understand the view of the International Law Commission as to whether it has engaged in codification of existing rules or rather in their progressive development. The reason for the judicial interest in this distinction has to do with the fact that courts determine the responsibility of a State which can only arise in relation to existing law.

In the first of the two above-mentioned cases, Al-Adsani $v$ the United Kingdom, the Grand Chamber of the European Court of Human Rights delivered its judgment on 21 November 2001. In the judgment, it made very little use of the work that had, at that stage, already been done by the International Law Commission in the field of sovereign immunity of States. The Court referred to the 1999 Report on Jurisdictional Immunities of States and their Property of the working group of the International Law Commission, but only to note "that national courts had in some cases shown sympathy for the argument that States are not entitled to plead immunity where there has been a violation of human rights norms with the character of jus cogens, although in most cases the plea of sovereign immunity had succeeded". ${ }^{27}$ After conducting its own analysis of the rules of international law in force at the time, the European Court of Human Rights could not "find it established that there is yet acceptance in international law of the proposition that States are not entitled to immunity in respect of civil claims for damages for alleged torture committed outside the forum State". ${ }^{28}$

The second judgment, in the case Jones and Others $v$ the United Kingdom, referred to and relied extensively upon the work of the International Law Commission. Delivered on 14 January 2014, the Jones judgment not only took into account the work that the International Law Commission had done in

$27 \quad$ Al-Adsani (n 24) para 23.
$28 \quad$ Ibid para 66. 
the relevant field in the more than 13 years that had elapsed since the adoption of the Al-Adsani judgment, but also referred to the International Law Commission's draft articles on the jurisdictional immunities of States (which had been adopted in 1991 and hence well before the Al-Adsani case was decided). ${ }^{29}$ Because the United Nations Convention on Jurisdictional Immunities of States and Their Property of $2004^{30}$ was not in force at the time of the Jones judgment and is still not in force today (having been signed by 28 States and ratified by 22 out of the 30 required States), ${ }^{31}$ the Court had to ascertain the contents of the rules of customary international law concerning sovereign immunities in cases where there are allegations of torture or breaches of other jus cogens norms. What is particularly interesting is that the European Court of Human Rights took into account the fact that the International Law Commission had been given an opportunity to revise the draft articles in order to incorporate an exception to sovereign immunity in cases where there had been torture but had not used this opportunity. ${ }^{32}$ This failure of the working group of the International Law Commission to propose amendments to the draft articles was one of the factors which led the Court to conclude that international law was developing in the direction where the jus cogens exception to the sovereign immunity rule would eventually become an established rule of international law but that this stage of development had not yet been reached. ${ }^{33}$

The approach of the European Court of Human Rights towards the work of the International Law Commission can be best described as casuistic. While it is most likely that the outcome of Al-Adsani and Jones would have remained unaffected by the depth of the study of the International Law Commission's materials, these cases clearly demonstrate the utility of the International Law Commission's function of codifying customary international law for the decision-making in Strasbourg. The two discussed cases also indicate the European Court of Human Rights' own reluctance to take the next step towards progressive development of law, although such progressive development cannot be ruled out when taking into account the dissenting opinions of some of the judges.

29 Jones (n 23) para 74.

$30 \quad$ Adopted 2 December 2004, not yet in force, UN Doc A/59/508.

31 United Nations Treaty Collection, 'Status of Treaties Deposited with the SecretaryGeneral' Ch 3, 13. < treaties.un.org/Pages/ViewDetails.aspx?src=TREATY\&mtdsg_no=III$13 \&$ chapter $=3 \&$ clang=_en $>($ as of 26 October 2018$)$.

32 Jones (n 23) para 79.

33 Jones (n 23) para 209. 
In view of the approach of the European Court of Human Rights towards the work of the International Law Commission, a few observations are warranted. Establishing a dialogue among these bodies is of great importance since both are involved in the development of international law broadly speaking through their respective competences. A better awareness of each other's work in the globalized world is necessary. Furthermore, courts such as the European Court of Human Rights are not necessarily composed of international lawyers. The trend that can be observed is that the domestication of international law has led to a reduction of the number of international lawyers in different fora which previously were composed of international lawyers to a significant degree. In view of the place of the European Court of Human Rights' judgments within the international legal system, the informal dialogue of the European Court of Human Rights and other courts and tribunals with the International Law Commission is a way to build mutual respect rather than confrontation. Secondly, one can already identify the issues that need to be discussed between these and other actors. These issues include the European Court of Human Rights' development of human rights law through a more flexible approach to the Vienna Convention on the Law of Treaties' interpretation criterion of subsequent State practice, which the Court sometimes simply calls a trend but which may nevertheless be sufficient to contribute to a judicial decision. In view of the International Law Commission's current work on custom and State practice and with a view to attributing more legitimacy to both the input and output of the Commission's work, such an exchange of views with courts would be very useful.

\section{Conclusions}

There are generally known constraints of time and resources at the disposal of the Commission. That may lead to questioning the possibility of a more prominent or all-embracing role of the Commission in a globalized world. I do not doubt that the availability of resources will have an impact on the definition of the Commission's role; however, that should not be the main or the primary factor in rethinking the Commission's role.

Furthermore, in view of some of the work accomplished by the Commission in recent years, the difficulties of maintaining the line between codification and progressive development is apparent. A good example in this respect are the articles on responsibility of States for internationally wrongful acts. Those articles have not only captured the attention of the International Court of Justice while they were being drafted but also became a point of reference for 
the European Court of Human Rights and domestic constitutional courts very early onwards. ${ }^{34}$ On the one hand, for courts in particular, it is important to know the view of the Commission as to whether it is engaged in codification or progressive development of law with regard to a particular topic. On the other hand, it ought to be also made clear that maintaining a conceptual distinction between the two may be a challenge, especially since the Commission works on a topic for several years and in the meantime international practice could already have been inspired by some of the views expressed by the Commission in its work. This reality of the world becoming smaller and faster, in my view, points even more to the importance of adapting the working methods of the Commission towards more openness, dialogue and communication which, on the one hand, is made easy in our digital époque and, on the other hand, may be more time-consuming in our pluralistic world. Such an adaptation of the working methods is necessary for the Commission to maintain its role, authority and legitimacy in international law-making. This line of reflection is particularly relevant with regards to the question of the Commission's competence to develop international law.

34 See the judgments of the Constitutional Court of the Republic of Latvia referring to the International Law Commission's draft articles on responsibility of States for internationally wrongful acts: Case no 2004-01-06 7 July 2004, 8 at para 3.2; Case no 2004-10-01 17 January 2005,14 . 